\title{
DISTRIBUTION OF THE CONSUMPTION TAX LOAD
}

\author{
JAMES W. MARTIN*
}

I

Tax students who have studied the distribution of the consumption tax load attack it theoretically from the angle of its effect on prices. The problem, thus, becomes one of incidence in the narrower economic sense of the word. ${ }^{1}$ Studied from this point of view, the variables which must be analyzed differ depending on the approach adopted. One stimulating and significant study ${ }^{2}$ places primary emphasis on whether the taxpayer subject to a commodity tax is a competitive or a monopolistic producer. In each instance these writers examine the problem according to the form of tax imposed-whether a specific, ad valorem, gross receipts, lump sum, or net return levy. An earlier student has suggested that the problem may be formulated in terms of whether transactions involved are all competitive, whether sellers produce at increasing costs, whether capital and labor employed in production are mobile or otherwise, and whether taxes are on the margin or on surplus. ${ }^{3}$ Still another writer has recently couched his inquiry primarily in terms of cost conditions among taxpayers. ${ }^{4}$ Some or all of these, together with other writers, also stress, among other factors, the question as to whether the taxes imposed apply to all or only a part of the competitive businesses, whether the rates are graduated, ${ }^{5}$ and how the proceeds of the taxes are actually expended. ${ }^{6}$

* A.B., 1920, East Texas State Teachers College; A.M., x92x, Vanderbilt University. Director, Bureau of Business Research and Professor of Economics, University of Kentucky. Research director, Interstate Commission on Conflicting Taxation, 1934:35; chairman, Tax Commission of Kentucky, 1936; commissioner of revenue of Kentucky, 1936-39. Member; President Roosevelt's Committee on Fiscal Relations between United States and District of Columbiá, 1936-37; American Economic Association, Royal Economic Society (England), National Tax*Association, National Association of Assessing Officers, Tax Policy League (now known as Tax Institute), Tax Research Foundation. Author, reports and government publications on taxation; editor, publications of Bureau of Business Research, University of Kentucky; contributor to professional journals.

The author's colleague, Mr. Glenn $D^{\prime}$. Morrow, has aided greatly in the preparation of this paper.

${ }^{2}$ See, e.g., Kendrick, Incidence and Effects of Taxation (1937) 27 AM. Econ. REv. 725.

${ }^{2}$ Fagan and Jastram, Tax Shifting in the Short Run (1939) 53 Q. J. EcoN. 562. See also Disctission (1940) 54 id. 665 .

${ }^{3}$ Edgeworth, Pure Theory of Taxation (Mar. x897) 7 Econ. J. 46, reprinted as first half of The Pure Theory of Taxation, in 2 Edgeworth, Papers Relating to Political Economy (1925) 63.

t Gilbert, Shifting of Sales Taxes (1939) 53 Q. J. EcoN. 275.

"Since most sales taxes are imposed at flat rates, this inquiry is largely irrelevant to the present immediate problem.

${ }^{\circ}$ In the last connection attention should be directed particularly to the stimulating discussion by Kendrick, Public Expenditure: A Neglected Consideration in Tax Incidence Theory (I930) 20 AM. EcoN. REv. 226, despite the fact that Kendrick, in common with Buchler, Public Expenditure and the Incidence of Taxes: Some Theoretical Considerations (1938) 28 AM. Econ. Rev. 674, appears to have neglected 
For purposes of this article, analysis in terms of individual taxes is likely to be more enlightening than analysis in terms of the more general and largely abstract studies which have been cited. As a type problem, consider general sales taxation. Although many writers have assumed that general sales taxes are shifted in their entirety to consumers, other students have seriously questioned this assumption.? The several careful studies which have been made ${ }^{8}$ show (r) that shifting is incomplete, at least in the immediate months following enactment; (2) that the proportion shifted varies with legal provisions and with administrative methods employed and depends heavily on the extent to which the particular sellers are subject to competition from outside the state; and (3) that, as might readily be assumed on the basis of theoretical considerations, heavier rates facilitate more complete shifting than do lower ones. In general, the conclusion that the retail sales tax is in the long run well-nigh completely shifted seems to be defensible except as disturbances are introduced by outside competition or by other exceptional factors. ${ }^{9}$ It might be well to note in this connection that the experience of Washington, Indiana, Mississippi, New Mexico, and West Virginia ${ }^{10}$ seems to indicate that general retail sales taxes are more completely shifted, as well as more adequately administered, when levied in conjunction with taxation of services and a more general system of sales taxation involving, in addition to retail sales, sales of wholesalers and manufacturers.

Statistical breakdowns have been developed in the various states to show the distribution of retail sales taxes among different classes of merchants. ${ }^{11}$ These disclose, for example, that the exact percentage of the total sales tax derived from sale of food products ranges from about 22 to less than 28 per cent of the total, depending heavily on the various other classes of commodities subject to the tax. There is considerable variation with respect to the proportion of the total supplied by public utilities, since one or two states do not include them within the purview of their taxes and certain others include only particular classes of public service enterprises. Moreover, the place in the total occupied by any particular class of business depends on the extent to which the state statistics completely classify all types of commodity groups.

Another approach is exemplified by the breakdown on a county basis to show

significant earlier writers. Smart and Hart, The Distribution of Revenues from State-Collected Consumer Taxes, infra this issue, present valuable data on this question.

${ }^{7}$ Cf. in this connection Riley, State Sales Taxes and the Cost of Food (1937) 44 Monthry Lason REv. 24I.

${ }^{8}$ Bell, Guyton and Sackett, Mississippi's General Sales Tax: How It Works (1933) UNIv. of Miss. Burx., Ser. 30, No. 3; Hatg and Shoup, The Sales Tax in the American States (1934); Jacody, Thi Retail Sazes Tax (1938).

${ }^{\circ}$ An interesting theoretical analysis which reaches a kindred conclusion is Brown, The Incidence of a General Output or a General Sales Tax: Will It Raise Prices? (1939) 47 J. Por. Econ. 254.

${ }^{10}$ For incidental evidence along this line see Halaas, The Sales Tax in State Systems With Particular Reference to Its Operation in Colorado (1937) I3 UNIV. OF DENVER REP. No. 3.

${ }^{11}$ Ibid.; Ford and Orkin, The Retail Sales Tax in Michigan (1936) UNIv. of Mrcr. (Bur. of Gov.) N. S. Busc. No. 6; Kansas Legislative Council, The Kansas Retail Sales Tax Fund (1938) Pub. No. 65; cf. Colm and Tarasov, Who Pays the Taxes? (x940) T. N. E. C. Monograpr No. 3, at 22. 
the extent to which farm, urban, mining, and other counties contribute to the total. Studies of this sort have been made for Michigan, ${ }^{12}$ and for Colorado and Wyoming. ${ }^{13}$ They seem to indicate that in the distribution of the tax load poorer farm territory has suffered in comparison with the urban communities and with the better farm territories. In Michigan, mining counties appear not to have fared as well as certain others.

The most significant, at least the most persistently used, analyses of the distribution of the general sales tax load among different income groups have rested on an investigation by Business Week. ${ }^{14}$ This report of American consumer expenditure budgets by income groups formed the basis of a pioneer sales tax incidence study by Dr. Mabel Walker, ${ }^{15}$ who undertook to show the percentage of net income required to pay a retail sales tax (on the assumption that the tax is shifted to consumers). Her study, quoted by numerous writers since, revealed the rate and the extent of regression in respect of food, housing, transportation, personal items, clothing, recreation, health, education, and civic expenses. More recent tax understanding adds to knowledge concerning incidence. One commentator, concluding an examination of sales taxation as a source of relief funds, ${ }^{16}$ has pointed out that use of the general sales tax to finance unemployment relief produces an anomaly in that the tax falls heavily on the unemployed and others whose income must be largely spent for taxable consumption. Collection methods also have their bearing. Thus the extent of regression under sales taxes depends, among other things, on whether consumers pay by brackets or utilize tokens. Regression is increased by the former policy; the administrative problem for the state, by the latter. ${ }^{17}$

Similar analyses have concerned selective sales taxes. With respect to beer and liquor excises, the assumption that the tax is incorporated in the price appears to be largely borne out by investigations, ${ }^{18}$ but the data also show that taxes have materially influenced the volume of business done. Perhaps the most significant statistical investigation of this nature has been made by the Bureau of Agricultural Economics for the Treasury Department. ${ }^{19}$ This study involves all the processing taxes and includes a tabulation revealing conclusions not only as to incidence but also as to immediate impact, effects on the processor's buying and selling prices, and the immediate consequences of repealing the taxes.

In addition to the studies of the incidence of particular consumption taxes, there has recently become available a significant report ${ }^{20}$ showing the distribution of the

\footnotetext{
${ }^{12}$ Ford and Orkin, stspra note II, at $20 . \quad{ }^{13}$ Falaas, supra note 10, at 9 et seq.

14 The Americans' Consumer Market: A Study by the Business Week (Sept. 7, I932) Bus. WEEx, I6.

${ }^{15}$ Where the Sales Tax Falls (General Welfare Tax League, 1934), also reprinted in Broompield, Sales Taxes: General and Retail (1934) 177.

${ }^{10}$ Ecker-R, The Sales Tax As a Source of Relief Revenue (F. E. R. A. Div. Research, Statistics and Records, $x 936$ ).

${ }^{17}$ On collection and enforcement aspects of consumption taxation, see Huston and Berryman, Collection and Enforcement of State Consumption Excise Taxes, infra this issue.

${ }^{18}$ Studenski, The Liquor Tax Problem Ahead (Jan. 24, 194I) J. Commerce 6.

${ }^{10}$ An Analysis of the Effects of the Processing Taxes Levied under the Agricultural Adjustment Act (U. S. Treas. Dept., x937). ${ }^{20} \mathrm{Colm}$ and Tarasov, supra note II.
} 
consumption taxes generally by income groups. It is apparent from the evidence, presented in Table I, that, although consumer taxes normally contribute to regression, the extent of inequality in the distribution of the total tax load, owing to the compensating influence of income and property taxes, is not great except as respects persons who earn definitely less than $\$ \mathrm{I}, 000$. That is, the higher aggregate rates on lower incomes are confined to the point at which the problem is most serious statistically and socially. There is evidence from comparison of this study with one made as of $1924^{21}$ that the area of definite regression on small incomes has been cut, and the extent of it within the narrowed range has become much more intense by reason of heavier consumer imposts.

TABLE I

Effect of the American Tax System on the Various Income Classes, in $1939^{22}$

Percentage of income paid out in taxes

Personal Taxes on

Income classes

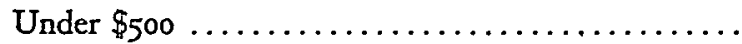

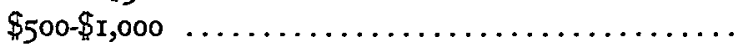

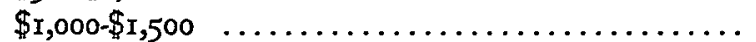

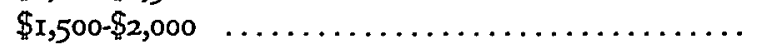

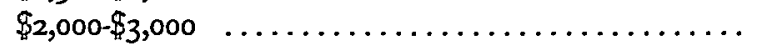

taxes

consumption

Total

I.3 $20.6 \quad 21.9$

$.9 \quad 17.1 \quad 18.0$

I.0 $\quad 16.2 \quad 17.2$

I.5 $\quad 16.4 \quad 17.9$

$1.5 \quad 15.9 \quad 17.4$

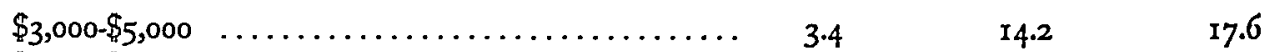

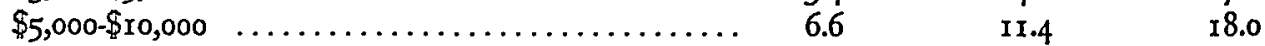

$\$ 10,000-\$ 15,000 \ldots \ldots \ldots \ldots \ldots \ldots \ldots \ldots \ldots \ldots \ldots, 16.6 \quad 25.6$

$\$ 15,000 \$ 20,000 \ldots \ldots \ldots \ldots \ldots \ldots \ldots \ldots \ldots \ldots \ldots, 23.9 \quad 31.6$

$\$ 20,000$ and over $\ldots \ldots \ldots \ldots \ldots \ldots \ldots \ldots \ldots \ldots, 32.5 \quad 3.2 \quad 37.7$

Total........................ $\overline{5.7} \quad \overline{14.5} \quad \overline{20.2}$

In considerable degree, the studies of incidence, whether in abstract or in statistical terms, fail to reach the entire problem. Generally, such studies assume static, and therefore non-existent, economic conditions. At least they ignore certain institutional factors and the entire temporal aspect of economic life. The general orthodox studies, moreover, couch their reasoning in terms difficult of practical application. For a legislator the problem of whether or not he should vigorously fight a sales tax on storage batteries produced in his district rests not on whether production occurs under conditions of increasing costs but rather on how the proposed tax will affect storage battery prices and sales volume. These considerations suggest, not that the usual approach is unsound or useless, but that the total impact of each consumer tax be fully investigated. The student needs to know as much as possible in both directions. For background policy decisions it is necessary to know, as nearly as possible, the incidence of each impost; but it is equally desirable to ascertain the over-all effects of the tax. ${ }^{23}$

${ }^{21}$ Shultz, Who Ultimately Pays the Taxes? (1924) 15.

22 Adapted from Colm and Tarasov, supra note II, at I3, Table Ib.

${ }^{23}$ Suggesting some approaches to over-all effects of consumers' taxes is the purpose of the second part of this article. Analysis of temporal considerations is deferred to a later paper pending further study. 
Numerous varieties of statistical and other evidence are available respecting the larger consequences of sales taxes. Some of these effects are inclusive of incidence and some of them are exclusively secondary in the sense that they do not include price readjustments. One class of effects arises from sales taxes imposed for restrictive purposes. Most of these measures seek to divert consumption from one channel to another. Illustrations may be found in the case of tobacco, alcoholic beverage, and margarine taxation. ${ }^{24}$

To outline the possibilities of productive study along this general line, certain concrete examples are presented. In I934 it was proposed that federal cigarette taxation be revised to approximate somewhat more closely an ad valorem basis without, however, abandoning the administrative advantages of the specific tax. In hearings before Congressional committees, much of the most significant testimony related to the discriminatory effects of the tax existing at that time or of the proposed tax, "depending on whose ox was gored." cultural Economics, both of which conducted an extensive study of the problem, maintained that the flat $\$ 3.00$ rate tended to shift cigarette tobacco consumption toward the more expensive grades of tobacco. In the view of these agencies, consumption of tobacco for cigarette purposes would probably be more nearly in proportion to the production of different grades, were there in effect the proposed thirty-cent tax reduction on cigarettes retailing for ten cents a pack. On the other hand, Mr. Junius Parker, ${ }^{26}$ tobacco company counsel, suggested that such a measure would tend to interfere with the demand for superior tobacco and thereby wreck the price structure.

A second illustration of tax measures designed to influence consumption is found in the case of wine taxes. Although several states have enacted such measures, ${ }^{27}$ perhaps the experience most discussed has been that of Michigan which, like Arkansas, Georgia, and New Mexico, provided a preferential tax rate if locally grown grapes were used in the manufacture of wine. As a consequence vineyards were so generously planted that the Michigan grape growers undoubtedly suffered more than any other persons from this legislation enacted in their behalf. ${ }^{28}$ Probably citizens of the state adopting such discriminatory legislation almost invariably suffer from it more than anybody else.

Another similar effect brought about in the case of a beer statute designed to

\footnotetext{
24 The use of consumers' taxes for regulatory ends is considered in Hart, Consumption Taxation as an Instrument of Economic Control, infra this issue.

${ }^{25}$ For a comparatively unbiased viewpoint see the testimony of Mr. Henry Morganthau, Secretary of the Treasury, A Statement on the Proposal to Reduce the Tax on Ten-Cent Cigarettes, Hearing Before the Senate Committee on Finance, 73d Cong., 2d Sess. (1934) 1 ; and for characteristic viewpoints respecting the two sides of the argument consider the statements of Mr. Wood F. Axton, id. at 5, and Mr. Junius Parker, id. at 13.

${ }^{20} \mathrm{Id}$. at 23 .

${ }^{27}$ See Comparative Charts of State Statutes lllustrating Barriers to Trade Between States (W. P. A. Marketing Laws Survey, r939) Chart 6, at 65 et seq.

${ }^{29}$ Melder, State Trade Walls (1939) Pub. Affarrs Inf. Paiphlet No. 37, at 22.
} 
favor Indiana brewers ${ }^{29}$ led to a complete embargo on Indiana beer in Michigan ${ }^{30}$ and Missouri. ${ }^{31}$

Similar provisions have been enacted with respect to distilled spirits.

A third illustration, which is perhaps more pointed because the tax is specifically designed to secure a preference, is found in the case of federal and state margarine taxes. These measures, first enacted by the Federal Government, have subsequently been passed by approximately half of the states. They are invariably intended to favor some particular variety or varieties of fats. The rates range up to fifteen cents a pound.

Data regarding the general effect of such measures are scarce. The influence of the federal tax, however, can be suggested by information respecting the volume of sales immediately before and immediately following the enactment in 1902 of the tax of ten cents a pound on artificially colored margarine. The total volume of margarine sales in rgoo and rgor averaged about ro6,000,000 pounds. The total volume in 1903 , the year after enactment, was $73,000,000$ pounds, declining to $50,000,000$ pounds in $1904^{32}$ A Department of Agriculture report $^{33}$ shows that the number of retail outlets handling margarine in the states having available statistics declined markedly after enactment of the taxes. The decrease averaged 52 per cent in states having a five-cent tax, $9 \mathrm{I}$ per cent in those having a ten-cent excise, and over 99 per cent in those collecting fifteen cents a pound. These drops occurred at a time when the margarine business was definitely increasing elsewhere. It appears from the evidence that no reduction in the number of licensees developed from specific requirements regarding the character of the margarine to be sold. ${ }^{34}$

A second variety of available evidence indicates that the amount of revenue collected from margarine excises varies inversely with the rate of the tax. The five-cent taxes raise considerable revenue; the ten-cent taxes raise some revenue but very much less; the fifteen-cent rates produce insignificant revenue..$^{35}$ Thus, the margarine tax constitutes another example of the effective use of the states' taxing power in behalf of an organized minority group to effect non-revenue purposes. ${ }^{36}$

With this tax, as in the case of most discriminatory revenue measures, retaliation has been quite the normal result; although reprisals from other states seem not to have been as numerous and as devastating as might reasonably have been antici-

\footnotetext{
${ }^{20}$ Townsend (Gov., Ind.), A State and Interstate Cooperation, in Proc. Nat. Conp. InTerstate Trude Barriers (Council of State Governments, 1929) 83. See also Ind. Stat. ANn. (Baldwin, 1934) c. 12. ${ }^{30}$ Mich. Stat. ANN. (Henderson, 1936) c. 175, §r8.rori, as amended by Mich. Pub. Acts 1937, No. $28 \mathrm{I}$.

${ }^{31}$ Mo. Stat. ANN. (I938) c. $3 \mathrm{I}, \S \S 4525-\mathrm{H}-2,4525-\mathrm{H}-4,4525-\mathrm{H}-5$. This measure was repealed by Mo. Laws 1939, p. 82x.

${ }^{32}$ Statistics from reports of the U. S. Bureau of Internal Revenue.

${ }^{33}$ Taylor, Burtis and Waugh, Barriers to Internal Trade in Farm Products (U. S. Dep't Agric., I939) 24.

st Ibid.

${ }^{35}$ Id. at 20; TAX SYSTEMS of THE WORLD (8th ed. 1940) 325, 354. It is of particular interest that the Wisconsin fifteen-cent tax produced only $\$ 283$ of revenue in 1937 , whercas in tho same year the five-cent tax of the smaller state of Iowa produced $\$ 304,918$.

${ }^{30}$ Cf. Stockwerl, Studies in California State Taxation, igio-ig35 (1939) 262; and consult symposium on Governmental Marketing Barriers (I94I) 8 Law \& Contemp. Prob. 207 et seq.
} 
pated. ${ }^{37}$ The Department of Agriculture report enumerates vigorous efforts to arouse unofficial embargoes against states imposing margarine taxes and adoption of formal resolutions by the Tennessee Federation of Labor, by the Arkansas General Assembly, and particularly by interested trade groups. ${ }^{38}$

In three respects consumption taxes have significantly restrictive effects even though imposed solely for revenue purposes: (I) violation of customary price, (2) elasticity of demand, and (3) inadequate administration. The effect most frequently overlooked is that arising from interference with customary prices. For instance, a tax is shifted forward in its entirety, but the volume of business is severely cut. In other cases, sellers may find it more palatable to assume the tax, or part of it, than to incur the loss in sales volume which shifting entails. Chewing gum, ice cream, soft drink, and general sales taxes are illustrative of incidentally restrictive consumer taxes which materially affect the business taxed, and sometimes related businesses as well, by reason of their disruption of a customary price. ${ }^{38}$

Before enactment of the Kentucky chewing gum tax of 1936, the price of the commodity had become well established at one cent a chew or five cents a pack. Imposition of the tax brought about a condition whereby dealers had to absorb the one-cent-a-pack tax, raise the retail price to six cents, or evade their liability. All three practices were attempted. If the price was increased by one cent the tax was successfully shifted, but the volume of consumption dropped so materially that the market was substantially destroyed. If the tax was absorbed, the profit for the small retailer was eliminated. If the retailer attempted to evade his obligation, ethical considerations aside, he rendered himself liable to serious penalties. The consequences of the measure would have been even more serious had the business been a major one for a considerable number of retail merchants.

Ice cream has been subjected to a 20 per cent tax in two states. The intent of these measures was to raise the price of ice cream cones from five cents to six cents in both South Carolina and Kentucky. It is reported in respect of the former that retailers enjoyed marked increases of five-cent candy package sales and corresponding reductions in ice cream cone business. ${ }^{40}$ In Kentucky the interference with ice cream cone business reduced sales by margins ranging from a few points to more than 60 per cent. ${ }^{41}$ Many dealers undertook to shift the tax by simply maintaining the fivecents-a-cone rate and reducing the amount of ice cream in each cone. Since, however, selling cones is primarily a service business and the cost of the ice cream is not

${ }^{37}$ Melder, World Situation and State Trade Barriers (Apr. 1939) I2 STate Gov. 68; and Taylor, Burtis and Waugh, supra note 33 , at 28 .

${ }^{38}$ See also Melder, Trade Barriers Between States (Jan. 1940) 207 Annazs 54; and Martin, Tax Competition Between States (Jan. 1940) 207 id. 62, 66-67.

${ }^{30}$ While ice cream, soft drink, chewing gum, and other excise taxes were in effect in Kentucky in 1936-1937, the author had opportunity as Commissioner of Revenue to know how these statutes operated. In what follows this miscellaneous information forms the basis of facts regarding Kentucky not otherwise credited.

"Derrick, Consumption Excise Taxes as Relief for the Tax Butden on Farm Property (1929) 22 Proc. Nat. Tax Ass'N 263.

${ }^{11}$ See Martin v. Nocero, $269 \mathrm{Ky} .15 \mathrm{I}$, $106 \mathrm{~S}$. W. (2d) 64 (1937); Shannon v. Hughes, $270 \mathrm{Ky} \cdot 530$, rog S. W. (2d) Ir74 (1937). 
a large proportion of total cost, the consequence of this policy was little better than that of adding the tax to the sale price or undertaking entirely to absorb it.

Another activity depending heavily on a customary five-cent price is the soft drink business. Certain data regarding taxes on this particular line are available for both South Carolina and Kentucky. In South Carolina, following imposition of the tax, there occurred a net reduction in the number of bottled-drink producers, in the fixed capital employed in the business, and in the value of the annual production. The value of the product, however, was cut less than other items. The facts in this particular case must be considered in the light of a general concurrent increase in other types of manufacturing. ${ }^{42}$ The annual reports of the South Carolina Tax Commission indicate, on the other hand, that tax receipts gradually increased from $\$ 877,5^{89}$ in 1926 to $\$ 1,046,245$ in I929. Moreover, the administrative official in charge indicated that in his judgment an excessive number of bottling plants had developed; and that the decline in number as well as the reduction in capital invested represented readjustments due to the previous over-expansion of plant capacity..$^{13}$

A Bottlers' Association study of the operating statistics of the larger bottled-drink manufacturers before, during, and subsequent to enactment of the 20 per cent tax in Kentucky ${ }^{44}$ showed that the rapid increase in the rate of the industry's growth in the state was retarded nearly 20 per cent although increase in out-of-state sales by the same producers continued at an accelerated pace. Moreover, after repeal of the tax in 1937, the bottlers regained the rate of increase in intrastate sales. Since the rate of gain was currently so great, however, it may be queried whether this showing is conclusive.

It has been asserted ${ }^{45}$ that violation of the customary prices even in the case of so low a rate as that imposed by a state retail sales tax brings about serious consequences in the case of men's haberdashery stores.

Incidental restrictions on business may arise from excise taxes on commodities or services the demand for which is inelastic. In one sense the tax policy which interferes with a customary price is merely one instance of this class of restriction. It occurs, however, in such a manner that only within a narrow price range is there known to be considerable elasticity of demand. In the case of certain types of commodities and services, a tax at any price margin appears materially to reduce volume.

This consideration of elasticity of demand has special significance in those cases in which the policy is to avoid restrictive influences on business. It is important to realize that elimination of a tax already imposed does not necessarily rectify the damage which the measure has occasioned, particularly if it has been effective for a considerable length of time. The tax may have greatly curtailed the business of

${ }^{12}$ Derrick, Constmption Excise Taxes for State Purposes (1928) 8 U. N. C. (Ext. Bull.) Studies IN Taxation in 6 .

${ }^{3}$ Tower, Luxury Taxation and Its Place in a System of Public Revenue (N. Y. Tax Comm., 1931) $86 \mathrm{n}$.

"A Report by the Kentuchy Bottlers'Association of Their Experience with the Special Soft Drinks Tax (undated).

${ }^{15}$ Willemsen, Operating Aspects of the Retail Sales Tax (I932) I I Harv. Bus. Rev. 10\%. 
some firms which have entirely retired. Again the ownership of businesses may have changed since the tax was enacted and its original impact felt by taxpayers. Thus, most of those who have been injured by the tax would not be aided if it were repealed; present enterprises would secure an unearned bonus. These considerations argue strongly for a large measure of stability in consumer-tax policy if the object of the state is to minimize interference with normal commercial activity. ${ }^{46}$

It must be kept in mind, moreover, that dealing with this kind of problem is complicated by the fact that frequently one cannot isolate the effect of the tax from that of other pricing factors. In many cases, also, the complication of business prejudice is present, so that one cannot estimate the extent to which the tax as such reduces volume of sales, as differentiated from the extent to which business is impaired by the unfortunate actions of management.

One interesting illustration is found in the $193^{2}$ federal tax on bank checks. This measure caused an average reduction in the volume of checks used of approximately 30 per cent, though the influence varied widely as between accounts. Thus, there was increased dependence on currency as a means of paying bills, particularly small ones where a two-cent tax is more than a negligible proportion of the total. If such a tax is imposed under conditions which require large use of currency, it provides a competitive demand for money which may interfere with other public purposes.

Most investigations of cigarette and gasoline tax effects have been made by interested parties, and there is some reason to believe that evidence contrary to the viewpoint of those conducting the studies was overlooked or not recognized. In the case of cigarette sales, for example, data have been circulated to show that the volume of cigarette business is much less in states that have cigarette taxes than in others. Thus it has been alleged that in non-taxing states cigarette consumption was $1,53^{1}$ cigarettes per person, while in those imposing taxes it was only $932 .{ }^{47}$ This statistician even goes so far as to apportion to non-taxing states the untaxed cigarettes sold in those states which do levy taxes. One figure is derived from state tax statistics, the other from federal statistics of withdrawals from manufacturing plants less the volume sold and taxed in those states which derive revenue from cigarettes. Of course, there is a real interference with the business when evasion of tax liability occurs. ${ }^{48}$ The contrary hypothesis is suggested by the present writer that practically no long-run restriction on volume occurs by reason of the state or federal tax on cigarette sales if it is adequately enforced.

The same conclusion applies even more emphatically to gasoline taxation. Several students have presented evidence to show that increased state taxes cut consumption of gasoline, interfere with sales of motor vehicles, or otherwise impede motor fuel or vehicle business. A committee of the National Tax Association, studying substantially similar data in I934, demonstrated that from 1932 to 1933 those states having

${ }^{10}$ Shoup and others, Facing the Tax Problem (r936) 245.

${ }^{\star 7}$ Cigarette Tax Blues: Tobacco Dealers Complain of Reduced Smoking (July 29, 1939) Bus. WEEK 22.

${ }^{8}$ SHOUP AND OTHERs, op. cit. supra note 46 , at 247 . 
the lowest gasoline tax rates showed decreases in fuel consumption, whereas those having higher rates showed increases; that those having the highest rates averaged mild increases in number of motor registrations, while those having the lowest rates averaged considerable decreases; and that those states which imposed local taxes in addition to state taxes averaged less decrease in gasoline sales volume than did states which lacked such measures. Its comment follows: "The committee desires to intimate that these data do not prove more than the figures submitted during the preceding years which suggested precisely the contrary conclusion. In a period of rapidly fluctuating business it is believed such data, standing alone, do not justify a generalized conclusion." $"$ It would be erroneous to say that the gasoline tax does not affect the petroleum business. It is reasonably clear, however, that, at current prices, gasoline taxes up to six or seven cents a gallon in the aggregate do not materially change the volume of fuel consumption.

The parimutuel betting tax which has shown rapid growth in the United States in the past few years provides a more valid and general illustration of elasticity than does a cigarette or a gasoline tax. Race tracks where parimutuel betting is conducted secure most of their revenue from admissions to the track and from the "take" deducted from winning tickets. Thus a tax is on the track whether the state charges a daily license, an admission excise, or an impost on gross parimutuel turnover. If the admission charge is raised by reason of an admission tax, the number of persons who attend racing meets is reduced. Again, boosting the parimutuel take may cut the number of betters and in addition reduce the number of persons who attend the meet, and the average quality of the race horses that compete may be lowered. Thus, track managements are solicitous to prevent heavy parimutuel taxes. Still, no state which has recently imposed a tax on parimutuel wagering has abandoned the policy ${ }^{50}$ and yet maintained legalized gambling.

Alcoholic beverage taxation illustrates invocation of elasticity of demand as a basis for deliberate control of consumption volume. The post-prohibition beer tax practice in the United States has sought to make the impost so moderate that malt beverage consumption would not be greatly cut, and hard liquor would be made less attractive. The whiskey tax policy in both the United States and Great Britain has sought to discourage consumption. Thus, the Colwyn Committee considered that the post-war English spirits taxes had decreased consumption but contended that such a decrease was certainly not inconsistent with sound public policy. ${ }^{51}$ It is important,

${ }^{10}$ Martin and others, Urgent Problems of Motor Velicle and Related Taxation (1934) 27 Proc. NAT. TAX Ass's 274, 280. In Effect of Gasoline Tax on Fuel Consumption (Dec. 17, 1930) Nat. Petroutum News, Mr. Harris and the present writer developed evidence that gasoline taxes do not restrict consumption even in the year following imposition except in the case of the very highest rates and except in those instances in which rates have been radically increased at one time.

"T Taxation of Parimuttel Wagering at Horse Races (Ill. Legis. Council, 1940) Pus. No. 27.

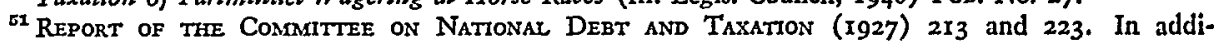
tion see SHoup AND OTHERs, op. cit. supra note 46, at 197; Tax on Intoxicating Liquor, Joint Hearings Before the House Committee on Ways and Means and the Senate Committee on Finance, 73d Cong., interim Ist and 2d Sess. (I933); Fosdick aNd Scotr, Toward Liquor Contror (r933); McConneli, Liquor Traffic (1933) 9 Encyc. Soc. Sciences 505; Williamson, Rates of Taxation of Beer and Spirits in Great Britain (1934) I2 TAX MAG. I72. 
in view of the generally admitted elasticity of demand for alcoholic products and particularly for any individual class of products, that legislative policy be formulated with a view to balancing revenue considerations against restrictive purposes at any particular stage. For example, Kentucky early in 940 increased its spirits tax rates from $\$$ r.04 a gallon to $\$ 1.20$ with the consequence that, despite a general upswing in tax revenues averaging approximately I7 per cent for the first half of the current fiscal year as compared with the same period of the preceding fiscal year, whiskey consumption revenues remained almost unchanged. ${ }^{52}$

Generalizations with respect to spirits apply with equal force to wines. ${ }^{\text {53 }}$ Pursuant to a recommendation by the State Department of Revenue, ${ }^{54}$ Kentucky in rg40 reduced the tax on small wine bottles. "This reduction in the tax rate seems to have stimulated the consumption of wine in small containers and contributed to the upward trend in receipts from the wine consumption tax."

Many discussions of tax theory rest on an assumption that tax administration is coordinate subject-matter rather than an aspect of tax theory. Certainly in many technical respects this assumption cannot be questioned. Recent experience makes it apparent, however, that the incidence and general economic effects of sales taxes are materially altered by administrative policy. Thus, administrative adequacy is certainly as significant an economic consideration in ascertaining the distribution of the tax load as is incidence theory in the narrow sense. Generally speaking, the difficulty in evenly shifting any consumer excise is well-nigh directly proportional to the extent of evasion.

It is thus important to find the reasons for poor administration and, in analyzing the distribution of the tax load, to consider the extent to which these imperfections can be eliminated. The most pervasive reasons for maladministration are lack of efficiency and of financial support. The main cure for the former appears to be improvement of field and office personnel, installation of a good system, and exclusion of partisanship from administrative policies. It is perhaps practically impossible to secure sufficient tax administration support, particularly because of the erroneous belief that performance at low cost means efficiency. A third factor contributing to inferior administration is our federal type of government. Impairment by this factor depends on the tax measure as well as on the geographical location of the state. Still a fourth variable bearing on administrative efficiency is margin of profit to the bootlegger. If the tax dodger can make a big gain from each operation the amount of evasion is likely to be much greater than if the income on each transaction is small. One illustration is the comparatively small volume of beer, as contrasted with the great amount of whiskey, tax evasion. ${ }^{56}$

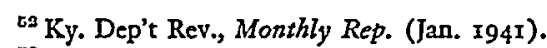

${ }^{53}$ Conlon, Taxation in the Alcoholic Beverage Field (1940) 7 LAW \& ConteMp. Prob. 737; Studenski, sttpra note 18, at 8.

¿' Ky. Dep't Rev., Twenty-first Ann. Rep. (1939) I9.

${ }^{20}$ Ky. Dep't Rev., Twenty-second Ann. Rep. (1940) 13.

${ }^{50} \mathrm{Sec}$ further on the problems of consumption tax administration, Huston and Berryman, supra note 17. 
Considerable evidence on the pyramiding of certain taxes is available. If the tax is levied early in the productive process, pyramiding is facilitated. ${ }^{57}$ If the rate is high, pyramiding is more likely, as well as more significant, than otherwise. The following Kentucky illustration has been suggested:58

The present $\$ 1.04$ excise tax is paid by the wholesaler, who invariably classes it as part of the cost of the whiskey. Thus, his mark-up of $I 7$ to 20 percent applies to the tax as well as the whiskey. The retailer's mark-up of 33 to $4^{\circ}$ percent is based on his purchase price, and again includes a mark-up on the excise tax. Instead of increasing the retail price of whiskey 13 cents per pint, this tax results in an increase of 20 to 22 cents. Because of the point of application of the tax, an extra 7 to 9 cents is paid to the wholesaler and retailer.

Studenski has cited New York City price data to the contrary-statistics which, in fact, raise a question as to whether the entire federal tax is shifted forward. ${ }^{50}$

${ }^{57}$ Studenski, supra note I8, at 6-7.

${ }^{5 B}$ Fowley, Alternative Sources of Revenue (1938) I.

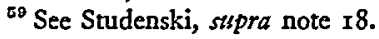

